\title{
Effects of fertiliser nitrogen management on nitrate leaching risk from grazed dairy pasture
}

\author{
IRIS VOGELER ${ }^{1}$, MARK SHEPHERD ${ }^{2}$ and GINA LUCCI ${ }^{2}$ \\ ${ }^{1}$ AgResearch, Palmerston North \\ ${ }^{2}$ AgResearch, Ruakura \\ iris.vogeler@agresearch.co.nz
}

\begin{abstract}
Dairy farms are under pressure to increase productivity while reducing environmental impacts. Effective fertiliser management practices are critical to achieve this. We investigated the effects of $\mathrm{N}$ fertiliser management on pasture production and modelled $\mathrm{N}$ losses, either via direct leaching of fertiliser $\mathrm{N}$, or indirectly through $\mathrm{N}$ uptake and subsequent excretion via dairy cow grazing. The Agricultural Production Systems Simulator (APSIM) was first tested with experimental data from fertiliser response experiments conducted on a well-drained soil in the Waikato region of New Zealand. The model was then used in a 20year simulation to investigate the effect of fertiliser management on pasture response and the impacts on potential leaching losses. The risk of direct leaching from applied fertiliser was generally low, but at an annual rate of $220 \mathrm{~kg} \mathrm{~N} / \mathrm{ha}$ exceeded that from urine patches in one out of 10 years. The main effect of $\mathrm{N}$ fertiliser on leaching risk was indirect via the urine patch by providing higher pasture yields and $\mathrm{N}$ concentrations.
\end{abstract}

Best management practices could include identification of high risk periods based on environmental conditions (e.g. soil moisture, plant growth), avoidance of fertiliser applications in these periods and the use of duration controlled grazing (DCG) to prevent excreta deposition onto the grazing area during critical times.

Keywords: Modelling, APSIM, N fertilisation rates, N fertilisation timing, direct and indirect leaching, urine patches

\section{Introduction}

New Zealand's freshwater quality is threatened by the impact of nutrient leaching from intensive agricultural production (Monaghan et al. 2007). Pressures are increasing to adopt farming systems that increase profitability, while reducing environmental impacts, including nitrogen $(\mathrm{N})$ leaching to ground and surface waters. In the last 15 years $\mathrm{N}$ fertiliser use on dairy farms has increased substantially (Gourley et al. 2012), with typical application rates ranging from
$100-200 \mathrm{~kg} \mathrm{~N} / \mathrm{ha} / \mathrm{yr}$ on dairy farms stocked at 3 cows/ ha (Shepherd 2009). Fertiliser efficiency is influenced by environmental and management practices, and generally decreases with increasing $\mathrm{N}$ inputs (Feyter et al. 1985), while $\mathrm{N}$ losses to the environment increase. Under pastoral grazing direct leaching from fertiliser is generally low, with urine typically contributing 70 to $90 \%$ of total $\mathrm{N}$ leaching losses (Legard et al. 2009). The pulse of $\mathrm{N}$ in the soil following fertiliser $\mathrm{N}$ application can, however, increase the risk of direct fertiliser leaching when followed by high rainfall events. Accurately matching $\mathrm{N}$ supply and demand is not easy, as substantial variations occur across years and within fields (Zebarth et al. 2009), and the risk of direct $\mathrm{N}$ leaching from fertilisers is likely to vary with soil type, growing conditions and the amount of drainage shortly following application. However, the main losses of $\mathrm{N}$ occur from urine patches (Oenema et al. 2005; Ledgard et al. 2009). Nitrogen fertiliser inputs indirectly affect this by providing more forage, enabling higher stocking rates, higher consumption and thus more $\mathrm{N}$ excretion. The amount of $\mathrm{N}$ excreted can be further exacerbated if the total plant $\mathrm{N}$ concentration is increased due to $\mathrm{N}$ fertiliser application (Hoekstra et al. 2008). Protein levels in New Zealand dairy pastures result in typical $\mathrm{N}$ contents of 3.4 to $3.9 \%$, and usually exceed the protein levels required by the lactating dairy cow grazing fresh temperate forages. The minimum protein requirements equate to an $\mathrm{N}$ content of $3 \%$, (Pacheco \& Waghorn 2008). Further increasing this mismatch by $\mathrm{N}$ fertilisation not only increases the amount of $\mathrm{N}$ consumed by the animal, but also the proportion of the excretal $\mathrm{N}$ that occurs in urine. The increase in pasture $\mathrm{N}$ content, however, depends on many factors, including season (growing conditions), rate of fertiliser $\mathrm{N}$ applied and the period between application and grazing (Shepherd \& Lucci 2013).

The objective of this study was to estimate the relative importance of both the direct and indirect effects of $\mathrm{N}$ fertiliser application on the risk of $\mathrm{N}$ leaching. This assessment was based on a combination of experiments and deterministic modelling using the Agricultural Production Systems Simulator, APSIM. We investigated the effect of $\mathrm{N}$ fertilisation rate and 
timing on (i) pasture yield, herbage $\mathrm{N}$ content, and risk of direct loss of fertiliser $\mathrm{N}$ by leaching, and (ii) the fate of the consumed herbage $\mathrm{N}$ and consequences for indirect leaching.

\section{Methods}

\section{Experimental Study Site}

Nitrogen response experiments were established in the 2010/11 dairy production season at AgResearch's Tokanui Research Dairy Farm, in the Waikato region of New Zealand. The soil was an Otorohanga silt loam, which is a well-drained soil of volcanic origin.

The experiments were conducted on four different paddocks where stock had been excluded for $>6$ months. The swards comprised perennial ryegrass (Lolium perenne L.) and white clover (Trifolium repens L.). Two of the paddocks were high in clover $(30-60 \%$ of total cut pasture dry matter (DM)) and the other two were low $(<10 \%)$. Each experiment included three urea fertiliser application rates: 0 (control), 35 , and $55 \mathrm{~kg}$ $\mathrm{N} / \mathrm{ha}$, with six replicates per treatment. Fertiliser was applied at these rates four times throughout the season, with two or three harvests of the pasture between each application to ensure that the total effect of $\mathrm{N}$ fertilisation on pasture growth was captured. Prior to each fertiliser application, the pasture was cut to a typical post-grazing residual pasture height equivalent to about $1700 \mathrm{~kg} \mathrm{DM} / \mathrm{ha}$. The second and third harvests after $\mathrm{N}$ application occurred at intervals of 3-5 weeks. For each harvest, a $3.6 \mathrm{~m}^{2}$ area of each plot was cut with a mower, weighed and a subsample (ca. 200 g) taken back for $\% \mathrm{DM}$ and $\% \mathrm{~N}$ determination.

Two of the sites (Group 1) received fertiliser applications on the same date in September, November, January and April. Application to the second group (Group 2) was delayed by 3 weeks between the two sites and received fertiliser in October, January, March and May. This gave a total of eight different fertiliser application timings (Figure 1) covering spring (September, October, November), summer (January early and late), and autumn (March, April, May).

\section{Model Setup}

All simulations were conducted using the APSIM modelling framework (www.apsim.info). The primary modules used in the simulation for this study included the soil module SWIM2, the SurfaceOM and SoilN modules for soil $\mathrm{C}$ and $\mathrm{N}$ transformations, and AgPasture for pasture growth and $\mathrm{N}$ uptake. Daily weather data from the NIWA Virtual Climate Station database (VCS) from the Tokanui site $\left(38.075^{\circ} \mathrm{S}\right.$, $175.325^{\circ} \mathrm{E}$ ) was used. A base simulation with the Otorohanga silt loam and a ryegrass/white clover sward was set up, with harvesting either according to the experimental setup or as described below for the long

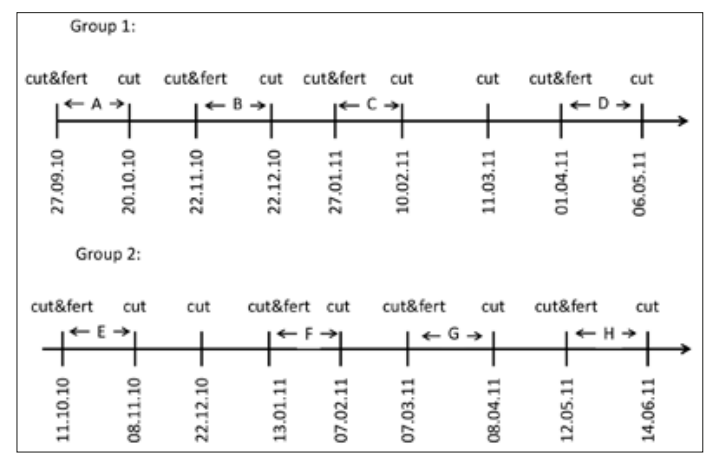

Figure 1 Experimental cutting and fertilisation schemes for the two different groups with two paddocks each, with $\mathrm{A}$ to $\mathrm{H}$ indicating the cuts used for the measurements of pasture $\mathrm{N}$ content.

term modelling. For most model parameters, default values were used. Exceptions were the water stress factor in the AgPasture module was set to 0.5 and the maximum temperature for growth to $35^{\circ} \mathrm{C}$, within the maximum range suggested by Berger et al. (2013). With these settings, appropriate model behaviour with the experimental data described in this study was obtained, with Nash-Sutcliff efficiency (NSE) values ranging between 0.32 and 0.46 . The NSE compares the model mean square error with the variance of the observations, and its value can vary from $-\infty$ to +1 , with NSE of 1 being the optimal value. Values between 0.0 and 1.0 are generally viewed as acceptable levels of performance (Moriasi et al. 2007).

Long term modelling was conducted to investigate the effect of year to year variability and $\mathrm{N}$ fertilisation management (rate and timing) on pasture growth, $\mathrm{N}$ fertiliser response, and risk of direct and indirect $\mathrm{N}$ leaching. Simulations were performed for each growing season from 1992/93 to 2011/12. The simulated harvest interval was 3 weeks throughout the year. Pasture was harvested to a residual mass of $1700 \mathrm{~kg} \mathrm{DM} / \mathrm{ha}$ on each occasion. Simulated N rates were 0,35 and $55 \mathrm{~kg} \mathrm{~N} / \mathrm{ha}$, applied in January, April, July and October in each year.

$\mathrm{N}$ leaching was defined as the predicted amount of $\mathrm{N}$ leached past a depth of $1 \mathrm{~m}$ in the year after application. The likely effect of $\mathrm{N}$ fertilisation on indirect leaching was calculated from the results of the long term modelling. The following assumptions were made:

- Based on the predicted DM yield following fertilisation and assuming a DM intake of $15 \mathrm{~kg} /$ cow/day, the number of grazing days available was calculated for the different fertiliser rates and seasons.

- An N partitioning model for dairy cows (Kebreab et al. 2002) was used to quantify the amount of $\mathrm{N}$ secreted in milk, urine, faeces, and retained in body tissues depending on the different fertiliser rates 
Table 1 Measured and simulated (APSIM) dry matter production (DM) at a low (LC) and high clover (HC) site, and corresponding pasture $\mathrm{N}$ contents in the first cut after $\mathrm{N}$ fertiliser applications ranging from 0 to $55 \mathrm{~kg} \mathrm{~N} / \mathrm{ha}$ on a ryegrass clover pasture in the Waikato region of New Zealand.

\begin{tabular}{|c|c|c|c|c|c|c|c|c|c|}
\hline & & & & \multicolumn{3}{|c|}{ DM [kg/ha] } & \multicolumn{3}{|c|}{$\mathrm{N}$ content [\%] } \\
\hline & \multirow{8}{*}{$\begin{array}{l}\bar{o} \\
\text { 윽 } \\
\text { 인 }\end{array}$} & Fert day & Cut day & LC & $\mathrm{HC}$ & APSIM & LC & $\mathrm{HC}$ & APSIM \\
\hline & & $27 / 09 / 10$ & $20 / 10 / 10$ & 807 & 1380 & 1307 & 3.2 & 3.4 & 3.1 \\
\hline & & $20 / 10 / 10$ & $22 / 11 / 10$ & 1016 & 1585 & 1906 & 2.1 & 3.0 & 2.8 \\
\hline & & $22 / 11 / 10$ & $22 / 12 / 10$ & 255 & 1073 & 396 & 3.0 & 3.8 & 2.5 \\
\hline & & $22 / 12 / 10$ & $27 / 01 / 11$ & 823 & 2079 & 1153 & 3.3 & 2.9 & 2.9 \\
\hline & & $27 / 01 / 11$ & $10 / 02 / 11$ & 471 & 549 & 514 & 4.1 & 4.6 & 3.1 \\
\hline & & $10 / 02 / 11$ & $11 / 03 / 11$ & 1589 & 834 & 1261 & 1.7 & 3.5 & 3.0 \\
\hline & & $1 / 04 / 11$ & 6/05/11 & 474 & 1369 & 999 & & & 3.0 \\
\hline & \multirow{7}{*}{$\begin{array}{l}\text { N } \\
\text { 옥 } \\
\text { 인 } \\
\text { U) }\end{array}$} & $11 / 10 / 10$ & $8 / 11 / 10$ & 1030 & 1931 & 1113 & 2.0 & 3.6 & 3.0 \\
\hline & & $8 / 11 / 10$ & $20 / 12 / 10$ & 1691 & 609 & 1011 & 2.2 & 1.7 & 2.4 \\
\hline & & $13 / 01 / 11$ & $7 / 02 / 11$ & 1213 & 1115 & 841 & 2.7 & 4.5 & 3.1 \\
\hline & & $7 / 02 / 11$ & 7/03/11 & 1088 & 1000 & 1215 & 2.6 & 2.3 & 3.0 \\
\hline & & 7/03/11 & 8/04/11 & 580 & 1109 & 1222 & 3.4 & 4.2 & 3.0 \\
\hline & & $8 / 04 / 11$ & $12 / 05 / 11$ & 904 & 391 & 875 & & & 3.0 \\
\hline & & $12 / 05 / 11$ & $14 / 06 / 11$ & 569 & 718 & 433 & & & 3.0 \\
\hline \multirow{14}{*}{ 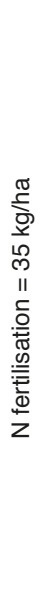 } & \multirow{7}{*}{$\begin{array}{l}\overline{-} \\
\text { 윽 } \\
\text { 인 }\end{array}$} & $27 / 09 / 10$ & $20 / 10 / 10$ & 1299 & 1822 & 1643 & 3.5 & 3.6 & 3.6 \\
\hline & & $20 / 10 / 10$ & $22 / 11 / 10$ & 1180 & 1669 & 2081 & 1.6 & 2.6 & 2.9 \\
\hline & & $22 / 11 / 10$ & $22 / 12 / 10$ & 313 & 1142 & 552 & 2.9 & 3.8 & 2.8 \\
\hline & & $22 / 12 / 10$ & $27 / 01 / 11$ & 978 & 2194 & 1513 & 3.0 & 3.2 & 3.1 \\
\hline & & $27 / 01 / 11$ & $10 / 02 / 11$ & 707 & 664 & 738 & 4.5 & 5.0 & 3.6 \\
\hline & & $10 / 02 / 11$ & $11 / 03 / 11$ & 2130 & 939 & 1348 & 1.9 & 3.5 & 3.2 \\
\hline & & $1 / 04 / 11$ & $6 / 05 / 11$ & 892 & 1670 & 1256 & & & 3.5 \\
\hline & & $11 / 10 / 10$ & $8 / 11 / 10$ & 1687 & 2126 & 1136 & 2.3 & 3.4 & 3.2 \\
\hline & & $8 / 11 / 10$ & $20 / 12 / 10$ & 1412 & 675 & 1158 & 2.3 & 1.9 & 2.5 \\
\hline & $\sim$ & $13 / 01 / 11$ & $7 / 02 / 11$ & 1561 & 1270 & 1098 & 3.2 & 4.2 & 3.5 \\
\hline & 응 & $7 / 02 / 11$ & 7/03/11 & 1136 & 1226 & 1278 & 2.7 & 2.3 & 3.2 \\
\hline & जั & $7 / 03 / 11$ & $8 / 04 / 11$ & 692 & 1288 & 1552 & 3.7 & 4.3 & 3.4 \\
\hline & & $8 / 04 / 11$ & $12 / 05 / 11$ & 1113 & 566 & 973 & 3.7 & 3.5 & 3.2 \\
\hline & & $12 / 05 / 11$ & $14 / 06 / 11$ & 1043 & 845 & 587 & 2.1 & 1.6 & 3.6 \\
\hline \multirow{14}{*}{ 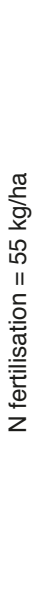 } & \multirow{7}{*}{$\begin{array}{l}\overline{-} \\
\text { 옹 } \\
\text { 이 }\end{array}$} & $27 / 09 / 10$ & $20 / 10 / 10$ & 1610 & 1952 & 1856 & 3.8 & 3.7 & 3.9 \\
\hline & & $20 / 10 / 10$ & $22 / 11 / 10$ & 1422 & 1625 & 2116 & 1.7 & 2.7 & 2.9 \\
\hline & & $22 / 11 / 10$ & $22 / 12 / 10$ & 322 & 1210 & 552 & 3.1 & 3.7 & 2.8 \\
\hline & & $22 / 12 / 10$ & $27 / 01 / 11$ & 1188 & 2117 & 1715 & 3.2 & 2.9 & 3.3 \\
\hline & & $27 / 01 / 11$ & $10 / 02 / 11$ & 733 & 688 & 738 & 4.4 & 4.9 & 3.6 \\
\hline & & $10 / 02 / 11$ & $11 / 03 / 11$ & 2322 & 1023 & 1348 & 2.2 & 3.4 & 3.2 \\
\hline & & 1/04/11 & $6 / 05 / 11$ & 1129 & 1769 & 1402 & & & 3.7 \\
\hline & \multirow{7}{*}{$\begin{array}{l}\text { N } \\
\text { 윽 } \\
\text { 인 }\end{array}$} & $11 / 10 / 10$ & $8 / 11 / 10$ & 2001 & 2235 & 1397 & 2.6 & 3.1 & 3.4 \\
\hline & & $8 / 11 / 10$ & $20 / 12 / 10$ & 1549 & 677 & 1223 & 2.5 & 2.0 & 2.5 \\
\hline & & $13 / 01 / 11$ & $7 / 02 / 11$ & 1677 & 1298 & 1230 & 3.3 & 4.3 & 3.7 \\
\hline & & 7/02/11 & $7 / 03 / 11$ & 1398 & 1352 & 1314 & 2.6 & 2.5 & 3.3 \\
\hline & & $7 / 03 / 11$ & $8 / 04 / 11$ & 756 & 1361 & 1714 & 3.7 & 4.3 & 3.6 \\
\hline & & $8 / 04 / 11$ & $12 / 05 / 11$ & 1241 & 655 & 972 & & & 3.3 \\
\hline & & $12 / 05 / 11$ & $14 / 06 / 11$ & 1153 & 920 & 593 & & & 3.6 \\
\hline
\end{tabular}



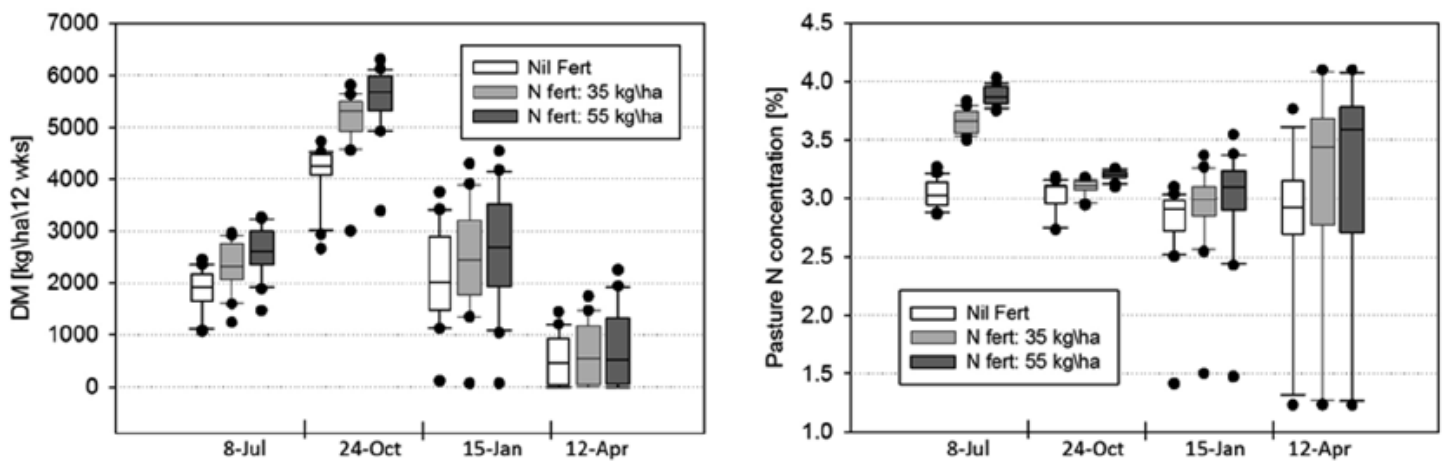

Figure 2 APSIM-simulated pasture dry matter production and $\mathrm{N}$ contents in the 12 weeks following fertiliser application at a rate of either 0,35 , or $55 \mathrm{~kg} / \mathrm{ha}$ in July, October, January or April to a ryegrass clover pasture in the Waikato region. The boxes show the 25th, 50th, and 75th percentiles, the whiskers the 5th and 95th percentiles, and the dots the outliers from simulations over 20 years (June 1992 to May 2012).

and seasons. This provided the $\mathrm{N}$ return, as dung and urine, to the paddock. Daily fluctuations in urine volume or urinary $\mathrm{N}$ concentration were not considered.

- Assuming a urination frequency of 10 events/day/ cow, and a urine patch area of $0.35 \mathrm{~m}^{2}$, the urine patch load and the urine affected area was calculated, assuming no urination overlaps.

\section{Results and Discussion}

Observed and simulated dry matter yields and pasture $N$ content

The two paddocks with the high clover content showed the highest annual yields in the absence of fertiliser (10.4 and $8.2 \mathrm{t} \mathrm{DM} / \mathrm{ha}$ ) compared to about $6 \mathrm{t} \mathrm{DM} /$ ha for the paddocks with low clover contents. As expected, pasture growth increased significantly after each fertiliser application (Table 1). However, the $\mathrm{N}$ fertiliser response efficiency varied between growing seasons and between paddocks. The response efficiency was higher in the paddocks with low clover content $(15 \mathrm{~kg} \mathrm{DM} / \mathrm{kg} \mathrm{N}$, mean across the 35 and $55 \mathrm{~kg} \mathrm{~N} /$ ha treatments) than in the paddocks with high clover content (7 kg DM/ $\mathrm{kg} \mathrm{N})$.

Measured pasture $\mathrm{N}$ contents were also variable (Table 1), most likely due to different growth rates and the effects of dilution of plant N. Pasture N contents were consistently higher in the higher clover paddocks, in agreement with Morton \& Risk (1994). Nitrogen fertilisation generally increased pasture $\mathrm{N}$ contents in the low clover swards, but not in the high clover swards, due to the buffering effect of nitrogen fixation. Applying $55 \mathrm{~kg}$ fertiliser $\mathrm{N} / \mathrm{ha}$ resulted in no change in mean pasture $\% \mathrm{~N}$ in the high clover swards (range -14 to $+8 \%$ change), compared with a $14 \%$ increase in pasture $\% \mathrm{~N}$ in the low clover swards (range $+1-$ $+35 \%)$.

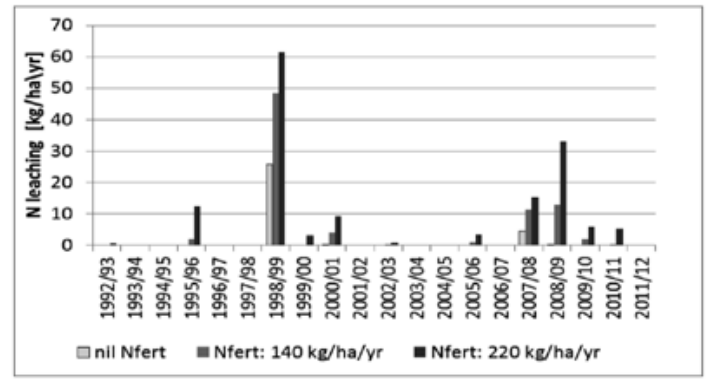

Figure 3 Simulated annual direct $\mathrm{N}$ leaching with different $\mathrm{N}$ fertiliser application rates, applied in even splits in January, April, July and October to a ryegrass clover pasture in the Waikato region of New Zealand.

\section{Long term modelling}

Year to year variation in pasture yields in the 12 weeks following fertilisation was substantial (Figure 2). Annual pasture yields without fertilisation ranged between 6.2 and $12.5 \mathrm{t} \mathrm{DM} / \mathrm{ha}$. Fertiliser increased these yields to means of 15.2 and $16.4 \mathrm{t} \mathrm{DM} /$ ha for the 140 and $220 \mathrm{~kg} \mathrm{~N} /$ ha treatments, respectively. Modelled average annual pasture $\mathrm{N}$ contents also varied widely, ranging between 2.8 and $3.1 \%$ with no fertilisation, and between 3.1 and $3.3 \%$ and 3.2 and $3.3 \%$ for fertilisation rates of 140 and $220 \mathrm{~kg} \mathrm{~N} /$ ha/year.

The risk of direct $\mathrm{N}$ leaching from the applied fertiliser was, in general, small over the 20 years simulated (Figure 3). However, in some years substantial N leaching was predicted, for example in 1998/99 (26, 48 and $61 \mathrm{~kg} \mathrm{~N} / \mathrm{ha}$ for the 0,35 and $55 \mathrm{~kg} \mathrm{~N} / \mathrm{ha}$ treatments, respectively). This was a combined effect of low pasture growth in the previous 1997/1998 period leading to accumulation of $\mathrm{N}$ in the soil, and rainfall of nearly $200 \mathrm{~mm}$ shortly following fertiliser application in July 1998. The resulting drainage was predicted to carry the applied fertiliser beyond the pasture root zone. 
Indirect leaching from $\mathrm{N}$ return via excreta is also likely to increase with $\mathrm{N}$ fertilisation. Increasing DM production through $\mathrm{N}$ fertilisation increases pasture production, and thus the total number of days available for grazing (Table 2). This increases the $\mathrm{N}$ returned via dung and urine, the latter usually being the major source of indirect leaching. Apart from the area affected by urination, urine $\mathrm{N}$ loads also increase significantly with increased $\mathrm{N}$ fertilisation, reflecting the increase in pasture $\mathrm{N}$ content. $\mathrm{N}$ loads of $839 \mathrm{~kg} / \mathrm{ha}$ are estimated under urine patches following $\mathrm{N}$ fertilisation in July at a rate of $55 \mathrm{~kg} \mathrm{~N} / \mathrm{ha}$. Assuming that $25 \%$ of the $\mathrm{N}$ from the urine patch leaches (Vogeler et al. 2013) indirect leaching losses from fertiliser would equate to 26, 37, and $43 \mathrm{~kg} \mathrm{~N} / \mathrm{ha}$ for the three different application rates. Thus, by increasing pasture DM and $\mathrm{N}$ contents, indirect leaching increases. According to this calculation, 42 to $45 \%$ of the increased leaching through fertilisation is due to the increase in pasture $\mathrm{N}$, and the remaining to increased pasture DM. This simple calculation does not account for the highly variable leaching between years, nor the effect of the timing of urine deposition on the risk of $\mathrm{N}$ leaching (Cichota et al. 2012).

The modelling results indicate that when deciding on best management practices for $\mathrm{N}$ fertilisation both direct $\mathrm{N}$ leaching from fertilisers and indirect leaching from urine patches need to be considered. At the higher annual rate of $220 \mathrm{~kg} \mathrm{~N} / \mathrm{ha}$ direct leaching exceeded that from urine patches in one out of 10 years. Best management practices could include identification of high risk periods based on environmental conditions (e.g., soil moisture, plant growth), avoidance of fertiliser applications in these periods and the use of duration controlled grazing to prevent excreta deposition onto the grazing area during critical times.

\section{ACKNOWLEDGEMENTS}

This work was conducted through the Pastoral 21 Environment Programme (C10X1117), jointly funded by the Ministry for Business Industry and Enterprise, DairyNZ, Fonterra and Beef + Lamb New Zealand.

Table 2 Effect of $\mathrm{N}$ fertilisation rate and timing on pasture dry matter (DM) yield and pasture $\mathrm{N}$ content in the 12 weeks following fertilisation (averages simulated by APSIM over 20 years); calculated total grazing days available depending on DM yield and assuming a daily intake of $15 \mathrm{~kg} \mathrm{DM}$; urine affected area assuming a urination frequency of 10 events/day and a urine patch area of $0.35 \mathrm{~m}^{2}$; estimated urinary $\mathrm{N}$ return based on DM intake and the Kaebrab model for partitioning $\mathrm{N}$ intake into milk products and excreta and assuming either uniform or patchy return; total $\mathrm{N}$ leached from the urine patches assuming that $25 \%$ of the total urine load is lost via leaching, and total $\mathrm{N}$ leaching from urine patches due to increased pasture DM only.

\begin{tabular}{|c|c|c|c|c|c|c|c|c|c|}
\hline & $\begin{array}{l}\mathrm{N} \text { rate } \\
{[\mathrm{kg} / \mathrm{ha}]}\end{array}$ & $\begin{array}{c}\text { DM } \\
\text { yield } \\
\text { [kg/ha] }\end{array}$ & $\begin{array}{c}\mathrm{N} \\
\text { content } \\
\text { of DM } \\
{[\%]}\end{array}$ & $\begin{array}{l}\text { Total } \\
\text { grazing } \\
\text { days } \\
\text { available }\end{array}$ & $\begin{array}{c}\text { Total } \\
\text { area } \\
\text { affected } \\
\text { by urine } \\
{\left[\mathrm{m}^{2}\right]}\end{array}$ & $\begin{array}{c}\text { Urinary N } \\
\text { concentration } \\
{[\mathrm{kg} / \mathrm{ha}]} \\
\text { equivalent }]\end{array}$ & $\begin{array}{c}\text { Total } \\
\text { urinary } \\
\mathrm{N} \\
\text { [g/cow/day] }\end{array}$ & $\begin{array}{c}\text { Total N } \\
\text { leached } \\
{[\mathrm{kg} / \mathrm{ha}]}\end{array}$ & $\begin{array}{c}\text { Total } \mathrm{N} \\
\text { leached if } \mathrm{N} \\
\text { content of DM } \\
\text { = nil } \mathrm{N} \\
\text { treatment } \\
{[\mathrm{kg} / \mathrm{ha}]}\end{array}$ \\
\hline \multirow[t]{3}{*}{ July } & nil & 1863 & 3.05 & 124 & 435 & 552 & 193 & 6.0 & 6.0 \\
\hline & 35 & 2337 & 3.66 & 156 & 545 & 761 & 266 & 10.4 & 7.5 \\
\hline & 55 & 2621 & 3.88 & 175 & 612 & 839 & 293 & 12.8 & 8.4 \\
\hline \multirow[t]{3}{*}{ October } & nil & 4145 & 3.04 & 267 & 967 & 548 & 192 & 13.3 & 13.3 \\
\hline & 35 & 5131 & 3.10 & 342 & 1197 & 568 & 199 & 17.0 & 16.4 \\
\hline & 55 & 5559 & 3.20 & 371 & 1297 & 602 & 211 & 19.5 & 17.8 \\
\hline \multirow[t]{3}{*}{ January } & nil & 2082 & 2.79 & 139 & 486 & 466 & 163 & 5.7 & 5.7 \\
\hline & 35 & 2450 & 2.91 & 163 & 572 & 505 & 177 & 7.2 & 6.7 \\
\hline & 55 & 2640 & 2.98 & 176 & 616 & 528 & 185 & 8.1 & 7.2 \\
\hline \multirow[t]{3}{*}{ April } & nil & 502 & 2.82 & 33 & 117 & 475 & 166 & 1.4 & 1.4 \\
\hline & 35 & 660 & 3.17 & 44 & 154 & 592 & 208 & 2.3 & 1.8 \\
\hline & 55 & 759 & 3.22 & 51 & 177 & 602 & 213 & 2.7 & 2.1 \\
\hline \multirow[t]{3}{*}{ Total } & 0 & & & & & & & 26.3 & 26.3 \\
\hline & 140 & & & & & & & 36.9 & 32.4 \\
\hline & 220 & & & & & & & 43.1 & 35.5 \\
\hline
\end{tabular}




\section{REFERENCES}

Berger, H.; Machado, C.F.; Agnusdei, M.; Cullen, B.R. 2013. Use of a biophysical simulation model (DairyMod) to represent tall fescue pasture growth in Argentina. Grass and Forage Science, doi: 10.1111/ gfs. 12064 .

Cichota, R.; Snow, V.O.; Vogeler, I.; Wheeler, D.M.; Shepherd, M.A. 2012. Describing N leaching from urine patches deposited at different times of the year with a transfer function. Soil Research 50: 694-707.

Feyter, C.; O'Connor, M.B.; Addison, B. 1985. Effects of rates and times of nitrogen application on the production and composition of dairy pastures in Waikato district, New Zealand. New Zealand Journal of Experimental Agriculture 13: 242-252.

Gourley, C.J.P.; Dougherty, W.J.; Weaver, D.M.; Aarons, S.R.; Awty, I.M.; Gibson, D.M.; Hannah, M.C.; Smith, A.P.; Peverill, K.I. 2012. Farm-scale nitrogen, phosphorus, potassium and sulfur balances and use efficiencies on Australian dairy farms. Animal Production Science 52: 929-944.

Hoekstra, N.J.; Struik, P.C.; Amburgh, M.E.V.; Lantinga, E.A.; Schulte, R.P.O. 2008. Can herbage nitrogen fractionation in Lolium perenne be improved by herbage management? NJAS - Wageningen Journal of Life Sciences 55: 167-180.

Kebreab, E.; France, J.; Mills, J.; Allison, R.; Dijkstra, J. 2002. A dynamic model of $\mathrm{N}$ metabolism in the lactating dairy cow and an assessment of impact of $\mathrm{N}$ excretion on the environment. Journal of Animal Science 80: 248-259.

Monaghan, R.M.; Hedley, M.J.; Di, H.J.; McDowell, R.W.; Cameron, K.C.; and Ledgard, S.F. 2007, Nutrient management in New Zealand pastures Recent developments and future issues: New Zealand Journal of Agricultural Research 50: 181-201.

Ledgard, S; Schils, R.; Eriksen, J.; Luo, J. 2009. Environmental impacts of grazed clover/grass pastures. Irish Journal of Agricultural and Food Research 48: 209-226.
Moriasi, D.N.; Arnold, J.G.; Van Liew, M.W.; Bingner, R.L.; Harmel, D.; Veith, T.L. 2007. Model evaluation guidelines for systematic quantification of accuracy in watershed simulations. Transactions of the ASABE 50: 885-900.

Morton, J.; Risk, W. 1994. Effects of triple superphosphate and Sechura phosphate rock on clover and nitrogen content of pasture. New Zealand Journal of Agricultural Research 37: 569-575.

Oenema, O.; Wrage, N.; Velthof, G.L.; Van Groenigen, J.W.; Dolfing, J.; Kuikman, P.J. 2005. Trends in global nitrous oxide emissions from animal production systems. Nutrient Cycling in Agroecosystems 72: 5165.

Pacheco, D.; Waghorn, G. 2008. Dietary nitrogen definitions, digestion, excretion and consequences of excess for grazing ruminants. Proceedings of the New Zealand Grassland Association 70: 107-116.

Shepherd, M. 2009. Identifying the decision making processes for application of $\mathrm{N}$ fertiliser to an individual paddock. pp. 177-186 In: Nutrient Management in a Rapidly Changing World, Eds. Currie, L.D., Lindsay, C.L. Fertiliser and Lime Research Centre, Massey University.

Shepherd, M.; Lucci, G. 2013. A review of the effect of autumn nitrogen fertiliser on pasture nitrogen concentration and an assessment of the potential effects on nitrate leaching risk. Proceedings of the New Zealand Grassland Association 75: 197-201

Vogeler, I.; Cichota, R.; Snow, V. 2013. Identification and testing of early indicators for $\mathrm{N}$ leaching from urine patches. Journal of Environmental Management 130: 55-63.

Zebarth, B.J.; Drury, C.F.; Tremblay, N.; Cambouris, A.N. 2009, Opportunities for improved fertilizer nitrogen management in production of arable crops in eastern Canada: A review: Canadian Journal of Soil Science 89:113-132. 